\title{
Theological resources for building resilience to gangster identity formations. A study of the Cape Flats
}

\author{
Vorster, Nico \\ North-West University \\ nico.vorster@nwu.ac.za
}

\begin{abstract}
This essay probes the remedial promise of Christian narratives on resilience in creating buffers against gangster identity formation on the Cape Flats. First, we consult and compare both quantitative and qualitative psychosocial studies on the causes of gangster identity formation on the Cape Flats. Thereafter, we discuss the dominant Christian narratives on resilience and examine their applicability and remedial potential for the specific social setting. The essay finds that the social settings within which gangster identities are formed determine to a large degree the kind of resilience competencies that have to be instilled in individuals and communities, as well as the type of theological discourse that ought to be followed. A certain type of theological discourse on resilience might be helpful in creating buffers against gangster identity formation within some communities of the Cape Flats, but the same narrative could yield negative results in others. The type of theological approach followed should therefore be closely aligned to the audience addressed to ensure that the competencies instilled in communities do not, in fact, grow into risk factors.
\end{abstract}

Key words

Gangsterism; Cape Flats; resilience; theology; identity formation

\section{Introduction}

Resilience denotes the dynamic processes involved in the human ability to cope with severe adversity or major threats; to resist destructive forces, events or processes; and to adapt constructively to setbacks or trauma. ${ }^{1}$

1 See Craig Steven Titus, Resilience and the Virtue of Fortitude. Aquinas in Dialogue with the Psychosocial Sciences (Washington: Catholic University of America Press, 2006), pp. 5-9; Suniya S. Luthar, Dante Cichetti and Bronwyn Becker, "The Construct of Resilience: A Critical Evaluation and Guidelines for Future Work”, Child Development 
The term is employed within a wide range of psychosocial disciplines such as socio-biology, evolutionary psychology, positive psychology, developmental psychology, developmental psychopathology and child development studies. A noticeable trend in modern resilience studies is the increasing multi-levelled approach employed by researchers. Whereas resilience studies were initially limited to research on child schizophrenics and family therapy, researchers nowadays focus on a broader array of factors that influence human resilience, such as physical characteristics, physiological stress factors, personal traits, social processes and spiritual coping mechanisms. Researchers also utilize a variety of theoretical models to examine the processes involved in human responses to challenges, ranging from personality models, cognitive models, and genetic models to developmental models and social-relationship models. ${ }^{2}$ These models attempt to identify the risk and vulnerability factors to which individuals or societies are exposed, and to enhance the emotional, intellectual and volitional competencies of human beings so that they can cope with the negative effects of adversity, resist self-annihilation and adapt positively to a new environment. ${ }^{3}$

Though the scientific conceptualization of resilience in the psychosocial sciences only dates back to the 1970's, Steven Titus rightly notes that the idea of positive adaptation to adversity is as old as humankind itself. ${ }^{4}$ In fact, themes such as perseverance a midst suffering, demonstrating patience despite trying circumstances, and turning bad experiences into positive opportunities are pervasive motifs in most religions.

This study explores the remedial promise of Christian-theological understandings of resilience with respect to gangster identity formations on the Cape Flats. We ask what role Christian discourses on resilience can play in building social buffers against gangster identity formation. 'Risk'

71, no 3, (2000): 543-562, 543. Luthar et al. identify significant adversity and positive adaptation to "assaults on the developmental process" as the two critical features of the notion of resilience, while Titus describes coping, resisting and constructing as the three critical facets in acts of resilience.

2 See Titus, Resilience and the Virtue of Fortitude, pp. 5-7.

3 Ibid., p. 17.

4 Ibid. 
refers in resilience studies "to any power that facilitates the start of, the digression to or the continuation of the problem situation."

Three methodological issues are pertinent to this study. First, we are concerned with a specific phenomenon within a particular social context that requires a certain type of resilience. To help us understand the phenomenon, we consult quantitative and qualitative psychosocial case studies conducted on gangster identity formation in the Cape Flats. By assessing the results of these studies, we hope to attain a better picture of the risk and vulnerability factors at stake in gangster identity formation in the Cape Flats region, as well as, the range of issues involved in the phenomenon.

Second, we focus on the potential of Christian-theological notions of resilience to be used as a resource for coping with social-political adversity, to resist the destruction of one's spiritual and ethical competencies, and to construct a positive non-violent response to socio-political challenges. ${ }^{6}$ The aim is not to develop a genealogy of Christian approaches to resilience, nor to provide an in-depth theological discussion of the concept, but rather to assess how these concepts can be used in a socially constructive manner within a diverse, multi-religious environment. Five dominant Christian theological motifs are identified that represent various angles and that developed within different social settings and historical ages. These are the Christ as example perspective, God as problem solver view; the character formation angle; the eschatological hope paradigm and the social liberation narrative.

Third, we seek to understand how the dynamics of the Cape Flats social context may influence the remedial usefulness, impact and messaging of the different types of Christian discourse on resilience. As noted earlier, we find a plethora of worldviews within the Cape Flats setting that range from Christian and Muslim understandings of reality to Africanist and secular outlooks on life. The fundamental questions asked are: Can the dominant

5 Doria Daniels \& Quinton Adams, "Breaking with Township Gangsterism: the struggle for place and voice," African Studies Quarterly 11, no. 4 (2010): 45-57, 46.

6 I borrowed the terms coping, resisting destruction and adapting constructively from Steven Titus's definition of resilience. See Titus, Resilience and the Virtue of Fortitude, 28. 
Christian notions of resilience be applied as a remedy to communities within the Cape Flats who are not necessarily receptive to Christian discourses? Are all of the Christian approaches equally valid in a plural context or should certain approaches be modified or even avoided when it comes to a specific contingent of the community?

\section{Gangster identity formation on the Cape Flats}

The Cape Flats comprises of urban ghettos such as Manenberg, Valhalla Park, Bonteheuwel, Athlone, Belhar and Mitchells Plain that lie south-east of the central Cape Town area. They stem from the forced relocation of about 700000 Coloured and African families between 1950 and $1982 .^{7}$ The apartheid government earmarked these areas in terms of the Group Areas Act (1950) for the relocation of "Coloured" people from rezoned "White areas". ${ }^{8}$ Houses were small and living conditions poor, while young people spent much of their time on the streets since their houses were overcrowded. ${ }^{9}$ The forced relocations fragmented family networks and uprooted social structures; while unemployment, poverty and overpopulation exacerbated the lack of social cohesion. ${ }^{10}$ Gangsterism has found a fertile breeding ground within this environment. MacMaster describes gangsterism on the Cape Flats as a "systemic phenomenon that is deeply rooted in certain communities." that operated in communities on the Cape Flats in the 1980s evolved after the political transition into sophisticated crime syndicates. ${ }^{12}$ Various

7 B. E. Van Wyk \& W. H. Theron, "Fighting Gangsterism in South Africa: A Contextual Review of Gang and anti-Gang Movements in the Western Cape", Acta Criminologica 18, no 3. (2005): 51-60, 53.

8 Nadine F. Bowers Du Toit, "Gangsterism on the Cape Flats," HTS Theological Studies 70, no 3 (2014): 1-7, 2. See Elaina Salo, "Negotiating Gender and Personhood in the New South Africa. Adolescent Women and Gangsters in Manenberg Township in the Cape Flats," European Journal of Cultural Studies 6, no. 3 (2003): 346-465, 347.

9 Van Wyk \& Theron, "Fighting Gangsterism", p. 53.

10 Doria Daniels \& Quinton Adams, "Breaking with Township Gangsterism, p. 47. Du Toit, "Gangsterism on the Cape Flats," p. 2.

11 Llewellyn MacMaster, "Social and Economic Emasculation as Contributing Factors to Gangsterism on the Cape Flats," Scriptura 95 (2007): 278-289, 281.

12 Van Wyk \& Theron, "Fighting Gangsterism", 53. 
studies have investigated the reasons why young males on the Cape Flats are attracted to gangs and why they become involved in gang activities.

$\mathrm{Du}$ Toit identifies the social power that gangs exert as a major cause. Gangs wield coercive social power through threats of violence, awarding status and rank to members, and handing out pay-outs and other financial benefits to members. ${ }^{13}$ They usually target youngsters from a low socioeconomic background who are in need of recognition, self-esteem, companionship and identity. ${ }^{14}$ The attraction of gangs therefore lies in them providing substitute identities to people who lack a sense belonging and are experiencing social alienation. The substitute identity nurtures a resistant mode of personhood and creates a new anchoring system that re-defines the self-image, challenges the status quo, enables individuals to adapt to a harsh environment, provides success and upward social mobility and gives the individual access to alternative forms of income. McMaster also notes that gangs often provide recruits with substitute father and brother figures who fill the lack of role models in their lives. ${ }^{15}$

The Cape Flats gangs distinguish themselves from the broader society and other gangs through striking names such as Naughty Boys, Junky Funky Kids or Ugly Americans. Through the years these labels have become household names that awaken a sense of awe and fear among some, and carry a celebrity status for others. ${ }^{16}$ Gangs instil substitute identities in their members by creating "brotherhoods" with moral codes and rituals. ${ }^{17} \mathrm{New}$ members are initiated through rites such as marking an area as a gang's turf, receiving tattoos or performing an outrageous act that proves loyalty.

13 Du Toit, "Gangsterism on the Cape Flats," 3.

14 Du Toit, "Gangsterism on the Cape Flats", 3; J. Wood \& E. Alleyne, "Street Gang Theory and Research. Where are we now and where do we go from here?" Aggression and Violent Behavior 15 (2010): 100-111, 106; Doria Daniels \& Quinton Adams, "Breaking with Township Gangsterism”, 54.

15 Llewellyn MacMaster, In Search of a Family. The Challenge of Gangsterism to Faith Communities in the Western Cape (D. Th.: Stellenbosch, 2010), p. 7.

16 MacMaster, "Social and Economic Emasculation", p. 279.

17 Steffen Jensen, "Claiming Community. Local Politics on the Cape Flats, South Africa. Critique of Anthropology 24, no. 2 (2004): 179-207, 180. 
The gangs in the Cape Flats are predominantly male driven. ${ }^{18}$ According to MacMaster, gang practices provide a ritual passage from childhood to adulthood. ${ }^{19}$ Members are usually expected to exhibit "manly" characteristics such as toughness, courage, loyalty, physical strength, sexual prowess and conquest. ${ }^{20}$ Tattoos representing a gang's insignia mark the young men's bodies as "physical boundaries" where different antisocial notions of personhood dominate, while gang graffiti identify and mark off gang turfs. ${ }^{21}$ Researchers note that these obsessions with hypermasculinity frequently develop in situations of disempowerment, since manly attributes are regarded as the only remaining avenue to bolster selfesteem, earn respect, express power and assert dominance. ${ }^{22}$

Gangs are able to provide young males with upward social mobility because they partake in a criminal economy that functions outside of the parameters of the formal economy. ${ }^{23}$ Whereas the formal economy tends to exclude low-skilled individuals, the criminal economy is accessible, provides a competitive advantage and frequently yields easy income. The criminal economy of the Cape Flats is driven by loose associations of street gangs that become part of larger criminal networks run by crime bosses and drug lords. ${ }^{24}$ These networks generate money through "tax revenues," drug smuggling, selling stolen goods and selling weapons. ${ }^{25}$ The crime bosses are often individuals who advanced through the ranks of street gangs. They exercise considerable social power, such as controlling access

18 Russel Luyt \& Don Foster, "Hegemonic Masculine Conceptualization in Gang Culture," South African Journal of Psychology 31, no. 3 (2001), p. 1.

19 MacMaster, In Search of a Family, p. 28.

20 Benita Moolman, “The Reproduction of an 'ideal' Masculinity though gang rape on the Cape Flats: understanding some issues and challenges for redress.” Agenda 18, no. 60 (2004): 109-124, 112, 115.

21 MacMaster, "Social and Economic Emasculation," 283. See Salo, "Negotiating Gender and Personhood", 351.

22 Russel Luyt \& Don Foster, "Hegemonic Masculine Conceptualization in Gang Culture", 2, 10. McMaster, In Search of a Family, 27.

23 See André Standing, "The Social Contradictions of Organized Crime on the Cape Flats," Institute for Security Studies, ISS Paper 74 (2003): 1-14.

24 Standing, "The Social Contradictions of Organized Crime", p. 3.

25 Ibid., p. 8. 
to areas, protecting emerging gangs and supplying gangs with weapons. ${ }^{26}$ The allegiance between emerging gangs, established gang structures and crime bosses sometimes trigger conflicts that could "escalate rapidly into a gang war." ${ }^{27}$ Yet gangs do not always act anti-socially. Some attempt to gain community support and boost their celebrity status through random handouts, sponsoring community sport events and engaging in other philanthropic actions. ${ }^{28}$ Kinnes notes that the activities of the gangs are sometimes supported by the community and that a number of incidents have occurred where the community attacked officers during police raids. ${ }^{29}$

\section{Theological resources for creating buffers against gangster identity formation}

Christian theological traditions have developed various approaches to resilience within different social settings in response to multiple social challenges. Though the term "resilience" has its origins in psychosocial studies, the Christian Scriptures employ expressions that convey related

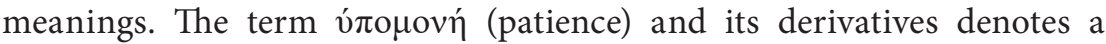
capacity to "bear up under difficult circumstance" or exhibit the capacity to endure afflictions; $\mu \alpha \kappa \rho \circ \theta v \mu \varepsilon \dot{\varepsilon} \omega$ signifies the ability to demonstrate patience despite difficulties and to display a state of calm amidst provocation, while

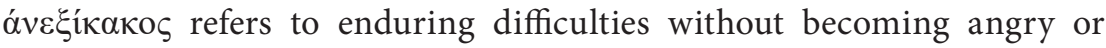
intolerant. ${ }^{30}$ However, to attain a true understanding of Christian notions of resilience, we need to move beyond terminologies to a discussion of the broader narratives that the Christian tradition employed to articulate their understanding of resilience. At the same time, we will discuss the applicability of the various discourses to the context of the Cape Flats.

26 Ibid., p. 4.

27 Ibid., p. 5.

28 MacMaster, "Social and Economic Emasculation", p. 286.

29 Irvin Kinnes, From Urban Street Gangs to Criminal Empires: The Changing Face of Gangs in the Western Cape, Monograph No 48 (Institute for Security Studies, 2000), p. 12.

30 Johannes P. Louw \& Eugene A. Nida, A Greek English Lexicon of The New Testament Based on Semantic Domains, vol 1 (Cape Town: Bible Society of South Africa, 1989), pp. 307, 308, See Romans 5:3, Jas 5:10, Heb. 6:12, 1 Thess 1:3; 2 Tim 2:24. 


\section{Christ as example}

The Christ as example discourse holds that Christ's life and human qualities exemplify the attitude that Christians should display when they encounter afflictions, suffering and persecution. Greco-Roman and Hellenistic-Jewish biographical literature often presented notable figures as moral examples to be emulated, while the Hebrew Scriptures called on the Israelites to follow the example of God by being holy as God is holy. ${ }^{31}$ This feature is also observable in New Testament literature. Capes states that the imitatio Christi served as an important impulse to write the Gospels and to provide a biographical account of Jesus's life. ${ }^{32}$ Imitation language specifically served "to encourage the faithful during periods of persecution" and to refuse "assimilation" with surrounding cultures and practices. ${ }^{33}$ Numerous passages in the New Testament describe the Christian moral life as an imitation of Christ's life, which is described as an example (v́ $\pi$ o $\delta \varepsilon \imath \gamma \mu \alpha){ }^{34}$

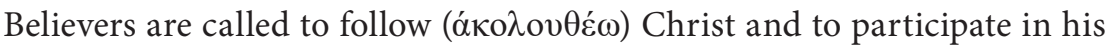
suffering by enduring persecutions and oppression for God's sake. ${ }^{35}$ Apart from the Gospels, various other New Testament passages identify Christ's attitude toward suffering and the patience with which he endured his own suffering as a prime indication of the endurance that Christians should display amidst suffering. ${ }^{36}$ The hymn of Philippians 2:5 for instance presents the crucified Christ as an example of acting unselfishly and showing humility amidst suffering; 1 Peter 2:21-23 calls on the faithful to regard their suffering as an opportunity to follow in the footsteps of Christ, the story of Stephen's martyrdom is presented in Acts 7 and 8 as an imitation of the passion of Christ, while the author of Hebrews 12:1-11 urges readers to look to Christ when they face exclusion and marginalization.

Early Christian writers picked up on the theme, specifically as persecutions became a constant threat in the lives of Christians. Willingness to die in

31 David B, Capes, "Imitatio Christi and the Gospel Genre," Bulletin for Biblical Research 13, no. 1 (2003): 1-19, 3. See Lev 19:2.

32 Capes, "Imitatio Christi", p. 1.

33 Capes, "Imitatio Christi", p. 9.

34 John 13:15. See Luke 9:62, Mark 10:17, 21; John 8:12; 1 Cor. 4:16; 1 Thess. 1:6; Eph 5:1.

35 Mark 8:34; John 12:25-26.

361 Thess 1:3, 2 Tim 3:11. 
martyrdom for the sake of Christ as Christ died for the cause of God and humanity, became a prominent apologetic theme in the works of early church fathers such as Ignatius of Antioch (died 110 ad), Polycarp (69 ad-155 ad), Justin Martyr (100-165 ad), Tertullian (155-240 ad), Origen (185-254 ad) and Athanasius (296-373 ad). ${ }^{37}$ Augustine (354-430 ad) identified fortitude as a cardinal virtue of Christian life. Fortitude entailed, according to Augustine, the ability to "bear all things for the sake of God," to forego earthly power and to endure pain "for the sake of the beloved." 38 Capes notes:

What is evident in all these early Christian texts is the notion that discipleship is perfected through martyrdom, particularly as it was accomplished in imitation of Christ's patient suffering. ${ }^{39}$

The notion of imitatio Christi received renewed prominence in the late medieval and early modern era, especially within mystic, monastic, pietistic and holiness movements who considered Christ as "the ideal of human personhood." ${ }^{40}$ Charles Taylor describes the period after 1000 as marked by a "steady growth" in "Christocentric spirituality" focusing on the suffering of Christ. This can be observed in the religious art of the times that contains various depictions of Christ's suffering on the cross; the stigmata movement; and the growing focus on Christ's piety and the saints as exemplary followers of Christ. ${ }^{41}$ Late medieval and early modern theologians such as Thomas a Kempis (1380-1471), John Bunyan (16281688), William Law (1686-1761, Samuel Johnson (1709-1784), and John Wesley (1703-1791) portrayed conformation to the image of Christ as the central aim of Christian spirituality. Being a disciple of Christ entails submitting oneself to God's providence, bearing afflictions patiently and

37 See James E. Bradley, "Miracles and Martyrdom in the Early Church: Some Theological and Ethical Implications," Pneuma: The Journal of the Society for Pentecostal Studies 13, no. 1 (1991): 65-81; 72-73.

38 See Elizabeth Agnew Cochran, "Jesus Christ and the Cardinal Virtues. A Response to Monica Hellwig, Theology Today 65 (2008): 81-94; 88, 91.

39 Capes, "Imitatio Christi", 17.

40 William G. A, Van Reyk, Christian Ideals of Manliness during the Period of the Evangelical Revival, 1730 to 1840 (DPhil thesis. Oxford: University of Oxford), p.25.

41 See Charles Taylor, A Secular Age (Cambridge: Belknap Press, 2007), p. 64. 
humbly and imitating Christ's perseverance in holiness despite temptation and affliction.

The Reformers resisted pietistic narratives and holiness ideals, but tied the imitation of Christ to cross theology. Luther held that Christ's cross and the believer's cross are closely connected. God makes himself known through Christ's suffering, and as God worked redemption through Christ's suffering, God works in the believer's life through physical and spiritual suffering. The duty of the Christian is to imitate Christ and to be willing to suffer martyrdom. ${ }^{42}$ Calvin, in a similar vein, emphasized the duty of believer to endure afflictions by following Christ in the manner that they bear their own crosses. ${ }^{43}$

After the Reformation, the Christ as example approach found particular expression in the moral-influence of Christologies of liberal Protestantism. Theologians such as Wilhelm Hermann (1846-1922), Albrecht Ritschl (1822-1889) and Albert Schweitzer (1875-1965) rejected high Christological notions of the two natures of Christ, atonement, the vicarious suffering and resurrection of Christ; in favour of the view that Christ was an exemplary moral teacher who left a lasting religious impression on human culture by exhibiting an authentic and ideal God-consciousness. ${ }^{44}$ The moral influence Christologies posited that believers are able to replicate the human qualities of Christ and to exhibit them in situations of psychological stress. ${ }^{45}$

The Christ as example motif contains various strengths that can be used to create social buffers against gangster identity formations on the Cape Flats. Though the acceptance of Jesus Christ as God and Saviour is a fundamental tenet of orthodox Christianity and should in my view not be abandoned; the example of Christ narrative can be applied to multi-faith or secular social contexts without requiring individuals to convert to Christianity.

42 See C. Matthew Phillips, "Bearing the Shame of the Cross. Luther's Theology of the Cross: The Imitation of Christ and Martyrdom," Logia 24, no. 2 (2015): 21-26, 22.

43 CO 2, p. 519.

44 See Gustav Aulèn, Christus Victor. An Historical Study of the Three Main Types of the Idea of Atonement (London: SPCK, 1931), p. 138; Alistair McGrath, Christian Theology. An Introduction. $4^{\text {th }}$ edition (Oxford: Blackwell, 2007), p. 301.

45 McGrath, Christian Theology, p. 302. 
The aim, after all, is to create buffers against distorted identities, not to Christianize society.

In fact, the notion of imitation is by no means foreign to Muslim audiences. Quran 33:21, for instance, calls on Muslims to imitate the prophet Mohammed in their conduct. The ideas of God's spirit being breathed into humans and the calling of human beings to imitate God by assuming his character traits is also established concepts in Islam, specifically in the Sufi tradition. ${ }^{46}$ Since Islam regards Jesus as a prophet, the example of the historical Jesus can be used in Muslim contexts as a tool to create buffers against militant identity formation.

The main strength of the Christ as example motif lies in its ability to provide an alternative to the hyper-masculine narratives that are so characteristic of gangster identity formation processes. Jesus Christ represents in many ways the anti-thesis of the alpha male. Whereas hyper-masculine values strive for pride, honour, domination, and achievement, Christ embodies the values of self-sacrifice, patience amidst suffering, humility and altruism. While hyper-masculinity equates power with violence and coercion, Christ represents a kenotic morality, an alternative course to conflict resolution, which responds to hostility by showing love to the enemy. ${ }^{47}$ Clearly, resilience to militant identity formation depends to a large degree on the ability of the individual and communities to internalize altruistic values, to seek peaceful methods of conflict resolution and to refrain from idolizing violence. The Christ as example narrative might provide an opportunity to kindle such values.

A second helpful feature of the Christ as example motif, which might be especially relevant to the Cape Flats social setting, is its ability to address the lack of role models in a society where fathers are often absent or do not represent the kind of successful role models that youngsters can identify with. Not only does Christ represent holiness and perfect obedience to the Father, but he represents a different kind of hero and an alternative mode of achieving success. Christ transformed reality by showing power in

46 See Nancy Roberts, "Imitatio Christi, Imitatio Muhammadi, Imitatio Dei”, Journal of Ecumenical Studies 47, no. 2 (2012): 227-248, 229.

47 Matthew 5:38-42. 
powerlessness, and countering afflictions by doing good. This characteristic of Christ could be employed as a means to counter the distorted heroic values on which gangs and terror networks thrive.

Another useful feature of the Christ as example discourse is its emphasis on enduring affliction patiently as Christ showed longsuffering in bearing his cross. Patience and forbearance are vitally important values to nurture in societies such as the Cape Flats that are going through periods of transition. The legacies of oppressive social systems cannot be undone in one generation, while factors beyond human control, such as economic recessions or natural disasters, could hinder social development. When it comes to opportunities for upward social mobility, a degree of patience is required.

The Christ as example motif also contains weaknesses. Altruism is an admirable personal trait that enhances social cohesion, but excessive altruism could make altruistic oriented persons vulnerable to abuse or create unwanted forms of dependency amongst receivers. Moreover, residents of the Cape Flats communities who were on the receiving side of an oppressive political system and who are still struggling with the systemic after-effects of apartheid, might find calls to altruism insulting.

An additional problematic feature of the Christ as example motif is the martyr ideal that was propagated by early Christian societies. Christian narratives that depict martyrdom as the ultimate form of discipleship could be extremely harmful, particularly in contexts where some young people might be indoctrinated to give their lives for the cause of Jihad. Karl Barth rightly notes that Christ's martyrdom had a once-off atoning effect, but human martyrdoms do not carry such an effect. Self-destruction does not bring positive benefits to others, except maybe, in very extreme circumstances. Barth proceeds to state:

The question remains, however, whether the good which is mediated by death is in fact good; and also whether the man on whose behalf death is dared is, in fact, good..$^{48}$

48 Karl Barth, The Epistle to the Romans, trans. Edwin C. Hoskyns (Oxford: Oxford University Press, 1968), p. 161. 


\section{God as problem solver}

The God as problem solver approach frames the believer's relationship with God as a direct, personal, intimate, interactive and problemsolving relationship. A life of prayer and closeness to God is regarded as fundamentally important, because the ambits of human agency and competencies are limited. God is seen as "a guiding force to problem solving," a role player in history itself who can change the course of history through miracle events and healings. ${ }^{49}$ This discourse is mainly inspired by a literal understanding of the miracle stories in the gospels and Acts. The gospels contain various healing, exorcism, nature, and revivification miracles. These narratives vary in form and function and convey multiple theological messages. ${ }^{50}$ The Synoptic Gospels, for instance, present Christ's healing powers and ability to exorcise demonic spirits as signs ( $\sigma \eta \mu \varepsilon i \alpha)$ of his divine power over the natural realm and his authority ( $\dot{\varepsilon} \xi o v \sigma i \alpha)$ over demonic forces, sin and death. ${ }^{51}$ Christ's miracles are depicted as acts that inaugurate the coming of the $\beta \alpha$ ci $^{\prime} \varepsilon \varepsilon \alpha$ (kingdom). ${ }^{52}$ The Johannine gospel, conversely, use miracle narratives to reveal Jesus's identity. They demonstrate Christ's dominion over nature, reveal his glory ( $\left.\delta \delta^{\xi} \alpha\right)$ and invite bystanders to faith. ${ }^{53}$ The Book of Acts goes beyond the gospels by portraying Christ's healing power as transferred to the church through the outpouring of the Spirit. Acts narrates various events where the apostles execute miracles in Christ's name. ${ }^{54}$

The church fathers generally exhibited an openness to the idea that God can intervene in the natural course of history through supernatural acts. They interpreted the New Testament miracle narratives literally and assumed that these events could repeat itself in the lives of believers. Though the early church fathers did not consider God's ability to intervene in human history and relief suffering as exempting believers from challenges and

49 Titus, Resilience and the Virtue of Fortitude, p. 57.

50 See Dorothy A. Lee, "Signs and Works": The Miracles in the Gospels of Mark and John", Colloquiem 47, no 1. (2015): 89-101, 89.

51 See Matthew 15:29-31; Mark 5, Luke 9:37-42.

52 See Dorothy A. Lee, "Signs and Works", p. 97.

53 John 2:11, 18; 4:48, 10:41. See Lee, “Signs and Works", p. 101.

54 See Acts 3:1-10, 5:1-12. 
hardship, we do encounter in their writings various narrations of divine intervention amidst persecution and accounts of miraculous healings. ${ }^{55}$ The same is true with regard to the Early and Late Medieval Ages. Religion was "everywhere" and "interwoven with everything," while the social imagination was generally characterized by a fascination with the supernatural realm, miracles and magic. ${ }^{56}$ The miracle narratives in the gospels were considered not only as unproblematic, but also as axiomatic expressions of the relationship between the supernatural and natural orders. This state of affairs changed during the Enlightenment with the rise of the rationalist scientific worldview. Enlightenment thinkers such as Thomas Jefferson and David Hume questioned the truth of the miracle stories in the gospels, while liberal Protestant theologians called for the reinterpretation and demythologizing of the miracle accounts in the gospels.

Despite the advances of modernism, the God as problem solver approach has resurfaced in the $20^{\text {th }}$ century with the rise of charismatic, Pentecostal and neo-Pentecostal movements. The main claim of these movements is that modern Christianity can "rediscover and re-appropriate the power of the Holy Spirit described in the New Testament and particularly the Acts of the Apostles." ${ }^{57}$ Some strands within these traditions place considerable emphasis on divine healing, while the so-called "prosperity gospel" has gained significant ground among neo-Pentecostal movements in the United States, Europe, Asia and Sub-Saharan Africa. Though not a "monolithic movement," prosperity theology generally holds that God wishes believers to prosper both materially and spiritually. Faith and repentance unleashes the positive healing powers of God, while it negates the negative and demonic powers that generate sickness, ills, diseases and poverty. ${ }^{58}$ True belief, consequently, leads to financial success and health.

The God as problem solver narrative contains some beneficial characteristics, but also highly problematic features. On the positive side, it provides

55 Bradley, "Miracles and Martyrdom in the Early Church," p. 71.

56 Taylor, A Secular Age, p. 2.

57 See McGrath, Christian Theology, p. 81.

58 Dan Lioy, “The Heart of the Prosperity Gospel. Self or the Savior?" Conspectus: The Journal of the South African Theological Seminary 4, no. 9 (2007): 41-64, 42. 
religious people with a sense of power by positing the existence of an omnipotent God who reigns providentially over the lives of his children. This transcendental outlook can reduce existential anxiety and induce hope in settings of despair and powerlessness. Secular and naturalistic worldviews are, in contrast, prone to nihilism and may reinforce feelings of despair in dire and challenging situations. They may also inadvertently contribute to a materialist, self-centred, winner-takes-all lifestyle that seeks coercive, and often illegal forms of power to gain upward social mobility.

The God as problem solver approach, moreover, recognizes the benefits attached to believers' engaging in a living relationship with God and partaking in rituals such as prayer, Holy Communion and baptism. Such practices create a sense of belonging among adherents and produce collective rituals of catharsis. ${ }^{59}$ The success of the God as problem solver approach obviously depends on the willingness of the audience to make a religious commitment. We can safely assume that the approach will have a limited effect on secular communities who regard monotheistic religious beliefs as outdated and based on an implausible worldview. Yet, it might yield some results within communities of the Cape Flats that exhibit an openness to religious worldviews. In fact, appeals to sacred values that encourage moderation might be more efficient when it comes to Muslim communities on the Cape Flats, than secular-liberal arguments based on natural reason or rights emanating from a universal human nature.

The confines of this study does not allow us to discuss the problematic theological assumptions that underlie the God as problem solver approach. We suffice with the criticism that this approach tends to create unrealistic expectations among adherents. Grudem ${ }^{60}$ rightly notes that "it is one thing to say that miracles might occur today. It is quite another thing to ask for miracles." Prosperity theology, which is making great inroads in the broader sub-Saharan region, is a particularly problematic version of the God as problem solver approach. Lay preachers often exploit poor people by promising them great wealth and prosperity if they convert to a particular

59 John F. Schumaker, Introduction in Religion and Mental Health, 3-30, ed. John F. Schumaker (New York: Oxford University Press, 1992), p. 3.

60 Wayne Grudem, Systematic Theology. An Introduction to Biblical Doctrine (Grand Rapids: Zondervan Publishing Press, 1994), p. 369. 
movement. High levels of guilt are generated among audiences and a fear for divine punishment is provoked to invoke an overwhelming, irrational and emotional response. The most troubling features of prosperity theology consist in the materialist orientation of the movement; the "paranoia" that it creates about sin, malevolent supernatural forces and evil; and the false expectations that are crafted to provoke thrill and excitement. Prosperity theology does not build buffers against militant identity formation, but actually increases the risk for social paranoia and pathological behaviour.

\section{Character formation}

The character formation motif probably represents the most general and dominant Christian approach to hardship. This line of thought portrays afflictions and challenges as opportunities for personal growth and character formation. Adversity is often depicted as an outcome of God's will who, driven by his mercy, grace and love, wants to transform us into better human beings through hardships. Without challenges in life there can be no development or growth. Hardships create and enhance human competencies, such as personal maturation, self-realization and the ability to persevere.

Some of the earliest Christian expressions of this approach are found in Pauline and Petrine passages. Romans 5:3-5 describes tribulations $(\theta \lambda i$ i $\varepsilon \sigma v)$ as providing us with an opportunity to cultivate and exhibit

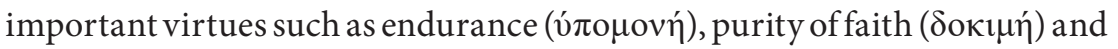
hope ( $\dot{\varepsilon} \lambda \pi i \delta \alpha$ ), while 1 Peter 1:6, 7 depicts trials as testing the genuineness of our faith and as purifying us from imperfections. Various other passages in the New Testament follow the same line of thought. ${ }^{61}$

Thomas Aquinas developed a teleological approach to character formation that had a profound influence on the Roman Catholic tradition. The teleological tradition largely depicted human life as consisting of a movement through our rational capabilities towards God who is the "Source of Truth" and "Universal Good."62 Our faculties are aided by God's grace, which infuses our habits or dispositions (internal principles

61 Cf James 1:3; James 5:10, 2 Timothy 2:24.

62 See Titus, Resilience and the Virtue of Fortitude, p. 103. 
of action) with God's guidance and motivates our will towards God. ${ }^{63}$ Ethical actions are driven, not in the first place by rules and obligations, but by virtues (theological, moral and intellectual), which are dispositions (formal causes) to act. The ultimate goal of moral acts is to flourish and to experience happiness which can only be attained by living in harmony with God. ${ }^{64}$ Following Augustine, Thomas Aquinas identified fortitude (fortitudo) as the key virtue at stake during situations of distress. Fortitude denotes the capacity to exhibit strength of mind amidst danger and threat, and to control fear. ${ }^{65}$ In fact, Aquinas considered fortitude as a cardinal virtue that informs and qualifies other virtues, since all virtues and most moral acts require some form of courage and firmness of mind. ${ }^{66} \mathrm{He}$ distinguished between various types of fortitude, namely magnanimity, magnificence, patience and perseverance. Magnanimity and magnificence are driven by acts of initiative taking, while patience and perseverance are inspired by acts of endurance. ${ }^{67}$

The Reformation rejected the teleological ethics of the Thomist tradition because of its philosophical premise that all human beings are naturally inclined to the good. The Reformers regarded this anthropological proposition as compromising the biblical doctrine of the total depravity of the human being. Nevertheless, the reformers embraced the idea that tribulations and hardships provide an opportunity for character formation. John Calvin, for instance, described cross-bearing as a core characteristic of a Christ-like life.$^{68}$ For Calvin, cross-bearing entails that we understand afflictions as a form of disciplining whereby God teaches us patience and endurance. By chastening us, God rids us of our self-love and urges us to repent and to conform our lives to the image of Christ. ${ }^{69}$

63 Ibid.

64 Ibid., pp. 99, 103.

65 Ibid., pp. 147-148.

66 Ibid. p. 148.

67 Summa Theologia II-II 123-143. See Titus, Resilience and the Virtue of Fortitude, pp. 146-148.

68 See John Leith, John Calvin's Doctrine on the Christian Life (Louisville, Kent.: John Knox Press, 1989), p. 38.

69 Inst. 3.6. 
Scientific advances after the Reformation forced Christian theologians to work out perspectives on the phenomena of natural evil and the suffering that accompanies evolutionary processes. John Hick $^{70}$ developed the influential perspective that challenges and hardships are essential for human "soul-making." Following the Irenaean notion that human beings were created good, but not perfect, Hick holds that human existence is a process that develops from incompleteness and immaturity towards a life that exhibits the likeness of God. The original fashioning of human beings (Homo sapiens) through processes of evolution only provides the raw material for the next stage, which consists in humans being spiritualized into children of God. ${ }^{71}$ In order for humans to reach their divinely intended destination, they have to respond to God's love and to embrace hardships. Without the presence of evils and trials, meaningful human development cannot take place. ${ }^{72}$

The character formation approach is well positioned to mitigate the effects of adversity in a wide range of settings. Muslims should be able to identify with the notion of an omnipotent God that forms our character through tribulations, while secular people might find the virtue ethical strand of the character formation narrative plausible, as long as it is based on a non-religious type of reasoning. The character formation narrative could be helpful in building resilience as it recognizes that pain is inherently part of our very existence, but also holds that hardships and challenges can be formative experiences in a person or communities' life and ought to be embraced as opportunities for personal growth. Importantly, the character formation approach maintains that suffering does not contradict the existence of a loving God, but that hardships could, in fact, be a sign of God's purifying love in action. Steadfast belief in the love of God and the sense that suffering is not meaningless per se, may console persons when they are confronted with vulnerability and may enable them to overcome traumatic experiences. Moreover, this approach maintains that God is omnipotent, that evil cannot undo God's creation and that suffering may

70 John Hick, Evil and the God of Love, $2^{\text {nd }}$ edition (London: MacMillan Press, 1977).

71 Hick, Evil and the God of Love, pp. 212, 255.

72 See Nico Vorster, “The Augustinian Type of Theodicy. Is it Outdated?" Journal of Reformed Theology 5, no. 1 (2011): 26-48, 42. McGrath, Christian Theology, pp. 231232 . 
also serve God's purposes. As noted earlier, belief in God's omnipotence, in the words of Kenneth Pargament, "equip individuals to respond to situations in which they come face-to-face with the limits of human power and control and are confronted with their vulnerability and finitude."

A valid criticism that may be levelled at the character formation discourse, specifically the evolutionary soul-making strand, is that it tends to romanticize suffering and attach meaning to evil, thereby underplaying the destructive, denigrating and senseless nature of extremely traumatic experiences. Some afflictions in life, such as being a victim of crime or rape, are so traumatic that it would be disrespectful to victims to portray such events as opportunities for character formation. In such circumstances, a person can only try to cope, to adapt to a new lifestyle, and to minimize the denigrating effects of the trauma on his or her life.

A second caveat relates to the use of fortitude discourse. The emphasis that the character formation narrative places on fortitude, courage and bravery is indeed important. All human actions, as Thomas Aquinas rightly points out, require fortitude in some form or another. We cannot take initiatives, construct things, do business or comfort others without exhibiting courage. However, when it comes to the setting of the Cape Flats, one should apply the fortitude narrative discreetly. One the one hand it is important that communities be encouraged not to allow gangs to instil fear in society or to limit their freedom of movement. Standing up to gangs not only requires bravery, but is a fundamental part of building social buffers against militancy. Conversely, when it comes to gangs, we need to take into account that they feed on heroic values. Extolling the virtues of magnificence and magnanimity in public without due consideration of the audience it is directed at, might yield unintended negative results. Titus rightly indicates that competencies that are generally considered as positive attributes can become vulnerabilities if practiced in an inappropriate manner. ${ }^{73}$

\section{Eschatological hope approach}

The eschatological hope paradigm originated in the twentieth century in response to the devastating effects that materialist and nihilist ideologies

73 Titus, Resilience and the Virtue of Fortitude, pp. 11, 14. 
such as Nazism and Communism had on European societies. Exponents of this paradigm emphasize themes such as the dialectical relationship between the cross and resurrection of Christ, human history as being taken up in the history of Christ, and the coming of God's kingdom. The topics of theodicy, hardship and suffering are seen from the perspective of the future; specifically the biblical promise that God is transforming reality through Christ and his Spirit. Our anticipation of the transformation that God's kingdom creates an active hope that all suffering and evil will be conquered. Two of the most influential exponents of this approach was Karl Barth (1886-1968) and Jürgen Moltmann (b 1928).

Karl Barth regarded creation as the external foundation of God's covenant with humanity and the covenant as the inner basis of creation. ${ }^{74}$ God's will is accomplished in human history though the redeeming work of Jesus Christ, who is Lord. Since everything was created for Jesus Christ and his death and resurrection, all things stand under the twofold contradiction of the cross and resurrection. ${ }^{75}$ Barth calls the reality that contradicts the existence of Christ and resists God's dominion "nothingness." It connotes an alien sphere of reality that has no authentic existence of its own, but consists in a privation of the good. ${ }^{76}$ "Nothingness" is that which was not created, willed or elected by God, but negated and judged. ${ }^{77}$ Christ conquers the powers of evil and "nothingness" on the cross and reveals his Lordship in the resurrection. Christ's death and resurrection consigns evil to the past and establishes the coming of God's Kingdom. Human resilience, therefore, consists for Barth in hoping on the glory of God. Yet, hope is about anticipation, we can never transform hope into a present reality, nor can we deny the "not yet" reality of the kingdom. ${ }^{78}$ Tribulations and calamities are part our paradoxical existence, but do not contradict or destroy our peace in God because we are already inheritors of God's kingdom and possess the security of redemption. Faith requires a willingness to believe in the midst

74 Karl Barth, Kirchliche Dogmatik. Die Lehre von der Schöpfung III/I (Zurich: Evangelischer Verlag, 1957), p. 103.

75 Vorster, “The Augustinian Type of Theodicy”, p. 38.

76 Karl Barth, Kirchliche Dogmatik. Die Lehre von der Schöpfung III/III (Zurich: Evangelischer Verlag, 1957), p. 327.

77 Ibid., pp. 375-376.

78 Karl Barth, The Epistle to the Romans, p. 153. 
of tribulation and to endure upheaval because we know that redemption is a "process in becoming." 79

Jürgen Moltmann's trilogy Theology of Hope (1964), The Crucified God (1972) and The Church and the Power of the Church (1975) approaches the problem of suffering from the perspective of God's power and His presence in our suffering. ${ }^{80}$ According to Moltmann, human history is grounded in the dialectical events of the cross and resurrection. The cross signifies death and the absence of God, while the resurrection represents life and the presence of God; the cross is an event of divine love, while the resurrection is an event of divine promise. ${ }^{81}$ God provides no theoretical answer to our suffering and does not abolish suffering, but shows his solidarity with our suffering on the cross by engaging in an act of divine suffering. This event is characterized by the Son suffering divine abandonment on the cross and the Father experiencing the grief of his Son's loss. Through this act of suffering in solidarity, God alleviates our "suffering in suffering," that is, our sense of being abandoned in suffering. ${ }^{82}$ The resurrection, conversely, opens up an eschatological future that contradicts present reality by setting in motion a historical process of radical divine renewal that will end all evil, suffering and death. This promise ought to arouse in us an active hope that anticipates the coming of God's kingdom. ${ }^{83}$

The eschatological hope approach is based on sophisticated theological reasoning. But will it have practical import for non-Christian communities on the Cape Flats? Though most Muslims share a belief in afterlife and immortality, they generally regard the notions of the Trinity, Christ's incarnation, and divine suffering on the cross as irreconcilable with the basic tenets of Islam. Secular oriented individuals, conversely, might find the transcendental orientation of the eschatological hope approach totally implausible.

79 Ibid., pp. 154-155.

80 Richard Bauckham, "Jürgen Moltmann," in David F. Ford and Rachel Muers (eds.). The Modern Theologians. An introduction to Christian theology since 1918 (Oxford: Blackwell publishing, 2005), p. 147.

81 Bauckham, “Jürgen Moltmann,” p. 148.

82 Bauckham, “Jürgen Moltmann,” p. 153.

83 Bauckham, “Jürgen Moltmann,” pp. 150-151. 
Perhaps the strength of the eschatological hope approach lies in what many perceive as its weakness, namely that it points us to an ultimate eschatological future that transcends our conception of time. It addresses the insecurity that mortality brings with afterlife beliefs and challenges materialistic and immanent worldviews by depicting present reality as a penultimate reality. In contrast to the God as problem solver narrative, this approach provides a careful analysis of the dialectical tensions involved in human existence and offers refined thoughts on the unfathomable nature of evil. At the same time it induces hope by claiming that we live in a penultimate reality, that the cross-event signifies God's solidarity with our suffering and that we may seek comfort in the coming of God's kingdom. Psychosocial studies have found that eschatological religious perspectives are surprisingly helpful in providing healing amidst difficulty, especially when persons experience trauma. ${ }^{84}$ Resilience to adversity, after all, requires hope, and hope requires spiritual coping mechanisms that transcend material reality and lift our eyes beyond the penultimate reality to an ultimate reality. In their psychosocial study of trauma, Peres, Moreira-Almeida, Nassello and Koenig states:

Religious beliefs and practices may reduce loss of control and helplessness, provide a cognitive framework that can decrease suffering, and strengthen one's purpose and meaning in the face of trauma. Religion can also provide a worldview that helps give purpose and meaning to suffering, besides hope and motivation. ${ }^{85}$

In a recent 2016 psychosocial study, O'Grady, Orton, White and Snyder in similar vein claim that resilience "requires spiritual processes and spiritual resources." 86 They base their argument among other things on a nationwide survey done in the United States after 9/11 that indicates that the vast majority (90\%) coped with the events by turning to religion. According to

84 See Julio F.P Peres, Alexander Moreira Almeida, Antonio Gladys Nasello and Harold G. Konig, "Spirituality and Resilience in Trauma Victims", Journal of Religion and Health 46 (2007): 343-350, 343. Titus, Resilience and the Virtue of Fortitude, p. 20.

85 Julio F.P Peres, Alexander Moreira Almeida, Antonio Gladys Nasello and Harold G. Koenig, "Spirituality and Resilience in Trauma Victims," pp. 347-348.

86 Kari O'Grady, James Douglas Orton, Kenneth White and Nicole Snyder, "A Way forward for Spirituality. Resilience, and International Social Science," Journal of Psychology and Theology 44, no. 2 (2016): 166-172, 166. 
them, "many people cope with traumatic or stressor events on the basis of their religious beliefs." 87

\section{Social liberation approach}

The social liberation narrative is typical of the family of liberation theologies that developed from the 1960's onwards as a response to political oppression, racial discrimination, poverty, gender inequality, and colonialism. Theologies belonging to this family include Latin-American liberation theology, feminism, black theology, Korean Minjung theology and Palestinian liberation theology. Though these theologies operate in different environments and focus on different experiences of oppression, they do share some fundamental theological premises such as a deliberate option for the poor, oppressed and marginalized; a focus on the cycles of domination and subordination that emanate from oppressive social and political structures; and an emphasis on the importance of advancing a liberating praxis that restores social justice.

The social liberation approach is highly critical of theistic, dogmatic, universalistic and pietistic theologies that are metaphysically oriented and socially disengaged. Instead of explaining the world, theology should transform the world. ${ }^{88}$ Social challenges should be confronted. Traditional altruistic Christian values such as patience and forbearance and eschatological approaches to the coming of God's kingdom should not be used to silence the voices of the oppressed and to perpetuate relations of domination and subordination. As God is a God of justice and takes the side of the poor, authentic theology starts from below by analysing the oppressive situations of the poor and marginalized. Non-theological tools of analysis are utilized to identify systemic causes of oppression. LatinAmerican liberation theologians, for instance, employed Marxist class analysis to criticize capitalism; feminism used linguistic hermeneutical tools such as deconstruction to highlight the male imagery that dominate patriarchal culture, while black theologians utilized reconstructive historiography to reconsider the ways in which slavery framed modern cultural dynamics and power structures. As liberation theologies spread

87 Ibid., p. 170.

88 See McGrath, Christian Theology, p. 90. 
all around the globe, methodologies have become increasingly intertwined and complex.

Scripture is generally seen by liberation theologians as a model for experience that provides liberating insights for practical situations of oppression. Special emphasis is placed on the notion of "structural sin". Society rather than individuals are corrupted by sin and in need of redemption. ${ }^{89}$ Various efforts have been made to re-interpret Jesus's history in order to develop contemporary Christologies that are relevant to situations of oppression..$^{90}$ The social liberation narrative typically portrays Christ as a liberator who identifies himself with the poor and oppressed. The cross denotes a place of struggle between Christ and the demonic oppressive forces of the world, while the resurrection and Pentecost signifies triumph and the birth of a new society. Some Latin-American liberation theologians characterize Christ as a freedom fighter, Minjung theologians describe Jesus as the personification of the Minjung consciousness that engages with the exploited, while black theologians such as James Cone depict Christ as black, since the Messiah is there where people are oppressed..$^{91}$

The strength of the social liberation narrative lies in it recognizing the "situatedness" of human existence, holding social systems to account and encouraging us to adapt constructively to adverse realities by countering oppressive social structures and resisting their denigrating impact. The situation on the Cape Flats is proof of the social liberation argument that "structural sin" and distorted power structures have a definitive impact on the lives of communities and individuals. Gangster identity formations on the Cape Flats are simply too widespread to ascribe it to pathology or dysfunctional personality traits. To address social ills on the Cape Flats, the role of apartheid and endemic poverty in dehumanizing communities and

89 See McGrath, Christian Theology, p. 91.

90 See Rebecca S, Chopp \& Ethna Regan, "Latin American Liberation Theology," in David F. Ford and Rachel (eds.), The Modern Theologians. An Introduction to Christian Theology since 1918 (Oxford: Blackwell Publishing, 2005), p. 474.

91 See Dwight N. Hopkins, "Black Theology of Liberation," in David F. Ford and Rachel (eds.), The Modern Theologians. An Introduction to Christian Theology since 1918 (Oxford: Blackwell Publishing, 2005), p. 456. Also see Archie Chi Chung Lee, "Contextual Theology in East Asia, in David F. Ford and Rachel (eds.), The Modern Theologians. An Introduction to Christian Theology since 1918 (Oxford: Blackwell Publishing, 2005), p. 523. 
uprooting family networks ought to be taken seriously, and appropriate structural counter measures should be taken. McMaster notes that the structural conditions of the communities of the Cape Flats have not been addressed "aggressively and radically enough to deny gangsterism its breeding ground." ${ }^{92}$ As long as upward social mobility is hindered by systemic structural factors such as endemic poverty, individuals will seek alternative methods, such as gangsterism, to gain upward mobility. Faith communities could play an important role in enhancing social resilience by being a public voice for the voiceless, focusing on structural issues such as re-establishing family networks, as well as asserting themselves as alternative communities of belonging.

The social liberation narrative can also be of value in non-Christian contexts, because of its focus on liberating praxis rather than dogma or ideology. A social liberation approach may assist in providing a voice for the voiceless by identifying the forms of social discrimination to which Cape Flat communities are subjected and by advocating just practices in the spheres of labour, housing and schooling. A fundamental ingredient of building buffers against militancy inevitably is to provide marginalized people with mechanisms that enable them to vent their anger and to change their situation constructively. If their voices are suppressed and avenues for self-expression closed, they may seek alternative mechanisms of coping, such as violence.

Despite its positive features, the social liberation narrative also has shortcomings.Somerightlyaccuseliberation theologiansofunderestimating the importance of personal accountability and overemphasizing the effects of social structures on individual behaviour. Though human beings are not self-contained beings, they are also not mere products of social structures or their environment, but have the capacity to say no to immorality and to resist adversity. When sin is attributed to structures rather than individuals and persons are not properly held accountable for their moral actions, the danger arises that they may abuse their status as "victims" of social oppression to justify deviant and anti-social behaviour. Such behaviour is in itself oppressive and detrimental to the well-being of others. The danger

92 MacMaster, In Search of a Family, p. 4. 
always exists that external blaming mechanisms can be employed in an inappropriate manner to justify violence against the state and society.

\section{Conclusion}

This essay probed the question: What role can the main Christian discourses play in building social buffers against gangster identity formation processes on the Cape Flats? Our discussion has shown that the dynamics of a particular setting and the risk factors involved have an important bearing on the kind of resilience competencies that should be encouraged in individuals and communities, as well as the type of theological discourse that ought to be followed.

Risk factors that drive gangster identity formation processes on the Cape Flats are feelings of despair and hopelessness, historic patterns of discrimination, low socio-economic status and a lack of social integration. Cape gangsters are largely driven by the promise of quick upward social mobility. They embrace violence as coping mechanisms, are driven by hyper-masculine values such as heroism and thrill-seeking, and tend to set clear boundaries between those belonging to the in-group and the external enemy.

Our survey has indicated that each of the dominant Christian narratives on resilience exhibit strengths and weaknesses. They may well produce varied results in the different settings. The Christ as example approach, the character formation discourse and the social liberation narrative are probably the best equipped to address wider audiences that do not hold Christian beliefs, yet the God as problem solver and the eschatological hope discourses may address conditions of despair and hopelessness more efficiently. The Christ as example perspective may be employed as a tool to counter the hyper-masculine narratives so endemic to gangster identity formation. Yet strands within this approach that propagate martyrdom ideals or excessive altruism could prove to be harmful. The God as problem solver approach may instil a sense of power in vulnerable people by positing the existence of an omnipotent God. Prosperity theologies, however, could create unrealistic expectations among the poor and inspire pathological forms of religion that increase social paranoia. The character formation perspective may empower individuals to cope with the effects of adversity 
in their lives through positive adaptation, but the "soul making" strands within the tradition tend to underemphasize the destructive and denigrating effects of trauma and evil. Moreover, the nurturing of heroic values, such as fortitude, ought to be applied judiciously within communities that are susceptible to distorted forms of heroism. The strength of the eschatological hope approach lies in it creating a spiritual coping mechanism that transcends penultimate reality, but it may have limited effects within strands of the community where many persons do not accept transcendent worldviews as plausible. Lastly, the social liberation discourse may enhance the resilience competencies of vulnerable communities by providing a voice to the voiceless, holding systems and structures to account and confronting forces that denigrate human existence. Unfortunately it tends to magnify the influence of structures on human conduct at the expense of holding individuals to account for deviant and anti-social behaviour.

In sum, Christian narratives on resilience have much to offer in creating buffers against gangster identity formation. Going forward, Christian resilience researchers may consider adopting a multi-dimensional approach that uses the various narratives interchangeably. This requires that the strengths of each narrative be maximized, while their shortcomings are avoided. Whatever approach is followed, due consideration ought to be given to the vulnerabilities and risk factors that affect specific settings. If not, some competencies impressed on communities may actually grow into risk factors.

\section{Bibliography}

Aulèn, Gustav. 1931. Christus Victor. An Historical Study of the Three Main Types of the Idea of Atonement. London: SPCK.

Barth, Karl. 1957. Kirchliche Dogmatik. Die Lehre von der Schöpfung III/I. Zurich: Evangelischer Verlag.

Barth, Karl, 1957. Kirchliche Dogmatik. Die Lehre von der Schöpfung III/ III. Zurich: Evangelischer Verlag.

Barth, Karl. 1968. The Epistle to the Romans, translated by Edwin C Hoskyns. Oxford: Oxford University Press. 
Bauckham, Richard. 2005. "Jürgen Moltmann," in David F. Ford and

Rachel Muers (eds.). The Modern Theologians. An introduction to

Christian theology since 1918 Oxford: Blackwell publishing. 147-163.

Bradley, James. E. 1991. "Miracles and Martyrdom in the Early Church:

Some Theological and Ethical Implications," Pneuma: The Journal of the Society for Pentecostal Studies 13 no. 1: 65-81.

Calvin, John. 2008. Institutes of the Christian Religion, translated by

Henry Beveridge. Peabody: Hendrickson Publishers.

Capes, David. B. 2003. "Imitatio Christi and the Gospel Genre," Bulletin for Biblical Research 13, no. 1, 1-19.

Chopp, Rebecca S \& Regan, Ethna. 2005. "Latin American Liberation Theology," in The Modern Theologians. An Introduction to Christian Theology since 1918, (eds.) David F. Ford and Rachel Muers. Oxford: Blackwell Publishing. 469-485.

Cochran, Elizabeth Agnew. 2008. "Jesus Christ and the Cardinal Virtues. A Response to Monica Hellwig”, Theology Today 65: 81-94.

Daniels, Doria \& Adams, Quinton. "Breaking with Township Gangsterism: the struggle for place and voice," African Studies Quarterly 11 no. 4, 45-57.

Du Toit, Nadine F. Bowers. 2014. "Gangsterism on the Cape Flats," HTS Theological Studies 70 no. 3, 1-7.

Grudem, Wayne, 1994. Systematic Theology. An Introduction to Biblical Doctrine. Grand Rapids: Zondervan Publishing Press.

Hick, John. 1977. Evil and the God of Love, $2^{\text {nd }}$ edition. London: MacMillan Press.

Hopkins, Dwight N. 2005. "Black Theology of Liberation," in The Modern Theologians. An Introduction to Christian Theology since 1918, (eds.) David F. Ford and Rachel Muers. Oxford: Blackwell Publishing. 451-469.

Jensen, Steffen. 2004. "Claiming Community. Local Politics on the Cape Flats, South Africa. Critique of Anthropology 24 no. 2, 179-207. 
Kinnes, Irvin. 2000. From Urban Street Gangs to Criminal Empires: The Changing Face of Gangs in the Western Cape, Monograph No 48 (Institute for Security Studies).

Leith, John, 1989. John Calvin's Doctrine on the Christian Life. Louisville, Kentucky: John Knox Press.

McGrath, Alistair. 2007. Christian Theology. An Introduction. $4^{\text {th }}$ edition (Oxford: Blackwell).

Lee, Archie Chi Chung. 2005. "Contextual Theology in East Asia," in The Modern Theologians. An Introduction to Christian Theology since 1918, (eds.) David F. Ford and Rachel Muers. Oxford: Blackwell Publishing. 518-533.

Lee, Dorothy A. 2015. "Signs and Works": The Miracles in the Gospels of Mark and John”, Colloquiem 47 no 1, 89-101.

Lioy, Dan. 2007. "The Heart of the Prosperity Gospel. Self or the Saviour?" Conspectus: The Journal of the South African Theological Seminary 4 no. 9, 41-64.

Louw, Johannes P. \& Nida, Eugene A. 1989. A Greek English Lexicon of The New Testament Based on Semantic Domains, vol 1. Cape Town: Bible Society of South Africa.

Luthar, Suniya S; Cichetti, Dante and Becker, Bronwyn. 2000. “The Construct of Resilience: A Critical Evaluation and Guidelines for Future Work", Child Development 71 no 3, 543-562.

Luyt, Russel \& Foster, Don. 2001. "Hegemonic Masculine Conceptualization in Gang Culture," South African Journal of Psychology 31.3, 1-11.

MacMaster, Llewellyn. 2007 "Social and Economic Emasculation as Contributing Factors to Gangsterism on the Cape Flats," Scriptura 95, 278-289.

MacMaster, Llewellyn. 2010. In Search of a Family. The Challenge of Gangsterism to Faith Communities in the Western Cape. DPhil thesis: Stellenbosch University. 
O'Grady, Kari; Orton, James Douglas; White Kenneth and Snyder Nicole. 2016. "A Way Forward for Spirituality. Resilience, and International Social Science," Journal of Psychology and Theology 44 no. 2, 166-172.

Pargament, Kenneth I. 1997. The Psychology of Religion and Coping. Theory, Research and Practice. New York: Guilford Press).

Julio F.P. Peres; Almeida Alexander, Moreira; Nasello Antonio, Gladys and Harold G. Konig. "Spirituality and Resilience in Trauma Victims”, Journal of Religion and Health 46 (2007), 343-350.

Phillips, C. Matthew. 2015. "Bearing the Shame of the Cross. Luther's Theology of the Cross: The Imitation of Christ and Martyrdom," Logia 24 no. 2, 21-26.

Roberts, Nancy. 2012. "Imitatio Christi, Imitatio Muhammadi, Imitatio Dei," Journal of Ecumenical Studies 47 no 2, 227-248.

Schumaker, John F. 1992. "Introduction," in Religion and Mental Health, 3-30, ed. John F. Schumaker. New York: Oxford University Press.

Standing, André. 2003. "The Social Contradictions of Organized Crime on the Cape Flats," Institute for Security Studies, ISS Paper 74, 1-14.

Taylor, Charles. 2007. A Secular Age. Cambridge: Belknap Press.

Titus, Craig Steven. 2006. Resilience and the Virtue of Fortitude. Aquinas in Dialogue with the Psychosocial Sciences. Washington: Catholic University of America Press.

Van Reyk, William G.A. 2007. Christian Ideals of Manliness during the Period of the Evangelical Revival, 1730 to c1840. DPhil thesis. Oxford: University of Oxford.

Van Wyk, B.E. \& Theron, W.H. 2005. "Fighting Gangsterism in South Africa: A Contextual Review of Gang and anti-Gang Movements in the Western Cape", Acta Criminologica 18 no 3, 51-60.

Vorster, N. 2011. “The Augustinian Type of Theodicy. Is it outdated?" Journal of Reformed Theology 5 no 1, 26-48. 